\title{
The Erwinia chrysanthemi EC16 hrp/hrc Gene Cluster Encodes an Active Hrp Type III Secretion System That Is Flanked by Virulence Genes Functionally Unrelated to the Hrp System
}

\author{
Clemencia M. Rojas, Jong Hyun Ham, Lisa M. Schechter, Jihyun F. Kim, Steven V. Beer, and Alan Collmer \\ Department of Plant Pathology, Cornell University, Ithaca, NY 14853-4203, U.S.A.
}

Submitted 14 April 2003. Accepted 30 January 2004.

Erwinia chrysanthemi is a host-promiscuous plant pathogen that possesses a type III secretion system (TTSS) similar to that of the host-specific pathogens $E$. amylovora and Pseudomonas syringae. The regions flanking the TTSSencoding hrp/hrc gene clusters in the latter pathogens encode various TTSS-secreted proteins. DNA sequencing of the complete $E$. chrysanthemi $h r p / h r c$ gene cluster and approximately $12 \mathrm{~kb}$ of the flanking regions (beyond the previously characterized hecA adhesin gene in the left flank) revealed that the $E$. chrysanthemi TTSS genes were syntenic and similar $(>50 \%$ amino-acid identity) with their E. amylovora orthologs. However, the hrp/hrc cluster was interrupted by a cluster of four genes, only one of which, a homolog of lytic transglycosylases, is implicated in TTSS functions. Furthermore, the regions flanking the hrp/hrc cluster lacked genes that were likely to encode TTSS substrates. Instead, some of the genes in these regions predict ABC transporters and methyl-accepting chemotaxis proteins that could have alternative roles in virulence. Mutations affecting all of the genes in the regions flanking or interrupting the $h r p / h r c$ cluster were constructed in $E$. chrysanthemi CUCPB5047, a mutant whose reduced pectolytic capacity can enhance the phenotype of minor virulence factors. Mutants were screened in witloof chicory leaves and then in potato tubers and Nicotiana clevelandii seedlings. Mu dII1734 insertion in one gene, designated virA, resulted in strongly reduced virulence in all three tests. virA is immediately downstream of hecA, has an unusually low $\mathbf{G}+\mathbf{C}$ content of $38 \%$, and predicts an unknown protein of 111 amino acids. The $E$. chrysanthemi TTSS was shown to be active by its ability to translocate AvrPto-Cya (a $P$. syringae TTSS effector fused to an adenylate cyclase reporter that is active in the presence of eukaryote calmodulin) into $N$. benthamiana leaf cells. However, $\operatorname{Vir} A_{(1-61)}{ }^{-}$

Corresponding author: A. Collmer; E-mail: arc2@cornell.edu

C. M. Rojas and J. H. Ham contributed equally to this work.

Current address of C. M. Rojas: Department of Molecular Microbiology, Washington University School of Medicine, 660 S. Euclid Ave, St. Louis, MO 63110, U.S.A.

Current address of J. H. Ham: Department of Plant Pathology, Ohio State University, 201 Kottman Hall, 2021 Coffey Road, Columbus 43210, U.S.A.

Current address of J. F. Kim: Laboratory of Microbial Genomics, Division of Genomics and Proteomics, Korea Research Institute of Bioscience and Biotechnology (KRIBB), P.O. Box 115, Yusong, Taejon 305-600, Republic of Korea.
Cya was not translocated into plant cells, and virA expression was not affected by mutations in E. chrysanthemi Hrp regulator genes $h r p L$ and $h r p S$. Thus, the 44-kb region of the $E$. chrysanthemi EC16 genome that is centered on the hrp/hrc cluster encodes a potpourri of virulence factors, but none of these appear to be a TTSS effector.

Type III secretion systems (TTSSs) are used by many bacterial pathogens of plants and animals to deliver virulence effector proteins into host cells (Cornelis and Van Gijsegem 2000; Galán and Collmer 1999). In plant pathogens, the TTSS is encoded by hrp/hrc genes, which are so named because mutants typically are unable to elicit the defense-associated hypersensitive response (HR) in nonhosts or in resistant host plants or to be pathogenic in host plants. The hrc genes represent a subset of hrp genes that are conserved in the TTSSs of both plant and animal pathogens. The Hrp TTSS has been studied most extensively in host-specific biotrophic pathogens, where several effectors, known as avirulence (Avr) proteins, have been shown to be delivered into plant cells by the Hrp system and to determine whether the outcome of the interaction is the HR or pathogenesis (Dangl and Jones 2001; Keen 1990). In contrast, the function of the TTSS and Hrp effectors in host-promiscuous necrotrophic pathogens, such as Erwinia chrysanthemi, has received less attention and is poorly understood.

The hrp/hrc gene clusters have been characterized extensively or fully sequenced in Pseudomonas syringae pv. syringae (Huang et al. 1995; Lidell and Hutcheson 1994), P. syringae pv. tomato (Fouts et al. 2003; Preston et al. 1995), Ralstonia solanacearum (Van Gijsegem et al. 1995), Xanthomonas axonopodis pv. citri and $X$. campestris pv. campestris (Da Silva et al. 2002), E. amylovora (Bogdanove et al. 1996; Kim et al. 1997), Pantoea stewartii subsp. stewartii (Coplin et al. 1992), E. herbicola pv. gypsophilae (Mor et al. 2001), and E. herbicola pv. betae (Nizan et al. 1997). The Hrp systems characterized so far fall into two groups that differ by the presence or absence of certain hrp genes, the organization of hrp/hrc genes within operons, and regulatory components (Alfano and Collmer 1997). Group I Hrp systems are present in P. syringae pathovars and Erwinia and Pantoea spp. and are activated by an alternative sigma factor, HrpL. Group II Hrp systems are present in $R$. solanacearum and Xanthomonas spp. and are activated by AraC-type regulators. Regardless of the group, hrp genes usually are repressed in complex media and induced in media that mimic apoplastic fluids, and they are flanked by genes encoding Hrp effectors and accessory type III secretion or translocation 
factors (Alfano and Collmer 1997; Kim and Alfano 2002). The latter observation reflects the general importance in bacterial pathogens of pathogenicity islands, which are clusters of genes with related functions in virulence that often show indications of horizontal acquisition (Hacker and Kaper 2000).

The presence of $h r p / h r c$ genes in the soft rot pathogens $E$. carotovora subsp. carotovora and E. chrysanthemi is puzzling because these pathogens attack their hosts primarily with an arsenal of type II-secreted pectolytic enzymes that cause tissue maceration and cell killing (Barras et al. 1994; Robert-Baudouy et al. 2000). The role of the Hrp system in E. carotovora is uncertain. In E. chrysanthemi EC16, the Hrp system appears to contribute to an early stage of pathogenesis, as demonstrated by E. chrysanthemi EC16 hrp mutants that were quantitatively reduced in the initiation of infection in witloof chicory leaves (Bauer et al. 1994; Yang et al. 2002). Similarly, E. chrysanthemi 3937, $h r p G$, and $h r c C$ mutants are impaired in lesion formation and growth in African violet leaves (Yang et al. 2002). In both strains, hrp mutations had stronger virulence phenotypes in mutants that produce only the secondary pectate lyase (Pel) isozymes because of deletions affecting the major Pels. The $E$. chrysanthemi EC16 hrp/hrc cluster has been cloned and shown to enable Escherichia coli to secrete $P$. syringae Hrp effectors (Deng et al. 2003; Ham et al. 1998). However, Erwinia chrysanthemi Hrp effectors have not been found, and the only native protein that is a candidate for TTSS secretion by E. chrysanthemi is the HrpN harpin (Bauer et al. 1995).

In an attempt to identify candidate Hrp effector genes in $E$. chrysanthemi, we have been exploring the regions flanking the $h r p / h r c$ genes, because these regions have been found to be rich in effectors in other plant pathogens (Alfano et al. 2000; Kim and Alfano 2002). For example, among pathogens with group I Hrp systems, the E. amylovora hrp/hrc-flanking regions contain genes encoding the harpins $\mathrm{HrpN}$ and HrpW and genes encoding the Hrp effector protein DspE and its likely chaperone, DspF (Kim and Alfano 2002). Similarly, Pantoea stewartii subsp. stewartii has a $d s p E$ homolog linked to the hrp/hrc gene cluster (Frederick et al. 2001). In Pseudomonas syringae, homologs of $h r p W, d s p E$, and other genes encoding other Hrp effectors are located in the conserved effector locus, which flanks $h r p R$ in the divergent strains $P$. syringae pv. tomato DC3000 and P. syringae pv. syringae B728A. In these strains, an exchangeable effector locus flanks the other side of the hrp/hrc cluster, beyond $h r p K$ (Alfano et al. 2000). The presence of genes encoding Hrp effectors in the regions flanking the $h r p / h r c$ gene cluster is also true for pathogens having group II Hrp systems. These genes include popA, popB, and popC in $R$. solanacearum (Salanoubat et al. 2002); xopA, xоpD, and hrpF in X. campestris pv. vesicatoria (Noel et al. 2002); and hpal in $X$. oryzae pv. oryzae (Zhu et al. 2000).

The region flanking the E. chrysanthemi EC16 hrp/hrc gene cluster beyond $h r p N$ contains an adhesin-encoding gene (hecA) and its cognate transporter-encoding gene (hecB) (Kim et al. 1998b), whose contribution to virulence is associated with adhesion to the plant epidermis and bacterial autoagglutination (Rojas et al. 2002). Genomic sequencing of the regions flanking the hrp/hrc cluster in E. carotovora subsp. atroseptica also revealed hecA and hecB homologs as well as sequences homologous to rhizobacterial genes involved in opine catabolism. More importantly, homologs of E. amylovora $d s p E$ and $d s p F$ were found adjacent to hecB (Bell et al. 2002), which would suggest that soft-rot Erwinia spp. also produce Hrp effectors.

Although the regions flanking the hrp/hrc cluster in several plant-pathogenic bacteria encode candidate Hrp effectors, not all of the genes in these regions encode proteins that travel the Hrp pathway. Additional criteria that have been used to iden- tify candidate Hrp effector genes in genomic sequences include linkage with promoters that are responsive to the HrpL alternative sigma factor and the presence of N-terminal aminoacid patterns and compositional biases that are characteristic of Hrp effector proteins (Fouts et al. 2002; Guttman et al. 2002; Petnicki-Ocwieja et al. 2002). The application of such sequence-based search methods and functional assays to the genome of $P$. syringae pv. tomato DC3000 has revealed the presence of 38 effector genes and several more candidates in the Hrp pathogenicity island and in other locations of the DC3000 genome (Buell et al. 2003; Collmer et al. 2002). Thus, Hrp promoter sequences, TTSS substrate-associated patterns, and homology with a growing list of effectors found in sequenced pathogen genomes provide new resources for identifying candidate effector genes in sequenced regions of the $E$. chrysanthemi genome.

We report here i) the complete sequence of the E. chrysanthemi EC16 hrp/hrc gene cluster; ii) DNA sequence analysis $7.9 \mathrm{~kb}$ beyond $h r c U$ (right flank of the $h r p / h r c$ cluster) and 4.4 $\mathrm{kb}$ beyond hecA (left flank of the hrp/hrc cluster) and evaluation of these regions for features that often are associated with Hrp effector genes; iii) construction of mutations affecting each open reading frame (ORF) (other than the $h r p / h r c$ genes) in the Hrp region of the E. chrysanthemi genome; iv) demonstration of a significant contribution of ORF11 (virA) to the virulence of $E$. chrysanthemi in witloof chicory leaves, potato tubers, and Nicotiana clevelandii seedlings; and v) evidence that the E. chrysanthemi TTSS is active in planta but does not activate virA gene expression or translocate the VirA protein into plant cells.

\section{RESULTS}

\section{The hrp/hrc cluster in $E$. chrysanthemi is collinear with the $E$. amylovora hrp/hrc cluster but also contains an intervening region in which three out of four ORFs appear functionally unrelated to the Hrp system.}

We completed the sequence of the E. chrysanthemi EC16 hrp/hrc cluster, which confirmed a gene organization similar to the previously characterized hrp/hrc clusters from E. amylovora (Bogdanove et al. 1996; Kim et al. 1997), Pantoea stewartii subsp. stewartii (Frederick et al. 2001), and E. herbicola pv. gypsophilae (Mor et al. 2001), which have group I Hrp systems (Fig. 1). The E. chrysanthemi EC16 hrp/hrc operons are preceded by Hrp box promoter sequences, and the predicted proteins exhibited more than $50 \%$ identity to their $E$. amylovora orthologs. Previous sequence analysis of the $E$. chrysanthemi hrp/hrc genes revealed several ORFs in an intervening region within the $h r p / h r c$ gene cluster. These are ORF2, ORF3, ORF4, and plcA (Fig. 1). None of these ORFs are preceded by recognizable Hrp promoters, and the N-terminal amino acids of these proteins have at least two deviations from the patterns associated with substrates of group I Hrp pathways (Petnicki-Ocwieja et al. 2002) (Fig. 1). For example, ORF2 begins with four hydrophobic amino acids and is not rich in Ser or other polar amino acids (Fig. 1B). In contrast, the HrpN harpin is preceded by a Hrp promoter and has all of the patterns associated with Hrp-exported proteins (Fig. 1B). ORFs 2 and 3 do not show any significant similarity to other proteins in the databases, but ORF4 has similarity to lytic transglycosylases.

\section{The regions flanking the $E$. chrysanthemi hrp/hrc cluster contain ORFs with no apparent functional relationship with the TTSS.}

We next sequenced $4.4 \mathrm{~kb}$ of $E$. chrysanthemi DNA in the left flank beyond hecA and $7.9 \mathrm{~kb}$ in the right flank beyond 
$h r c U$ and searched for ORFs that were preceded by Hrp promoter sequences, or showed similarity to known Hrp-related proteins, or possessed N-terminal amino-acid patterns associated with proteins that are secreted by the Hrp system (Fig. 1B). In contrast to other plant pathogens whose Hrp regions had been similarly sequenced, E. chrysanthemi had no ORFs that appeared to be Hrp TTSS substrates (Table 1). With the exception of ORF1, which resides between hecB and $h r p N$, no ORFs were preceded by recognizable Hrp promoter sequences (Fig. 1A). The N-terminal amino acids of ORF1 and all other proteins encoded in the regions flanking the $h r p / h r c$ cluster have at least two deviations from the patterns associated with substrates of group I Hrp pathways (Petnicki-Ocwieja et al. 2002). For example, ORF1 lacks a hydrophobic amino acid in positions 3 or 4 and is not rich in Ser and other polar amino acids (Fig. 1B).
However, some of these ORFs have homologies that suggest a potential role in virulence or in interactions with the biotic environment (Table 1). ORF1 in the left flanking region is similar to one of the products of a polyketide synthesis gene cluster that is responsible for the production of the antibiotic curamycin (Kim et al. 1998b). ORFs 5 to 10 in the right flanking region encode putative membrane proteins that have sequence similarity to $\mathrm{ABC}$ transporters and a chemotaxis protein. The closest homologs to these proteins are in other enterobacterial pathogens. ORFs located in the left flanking region also include hecA and $h e c B$, whose role in virulence has been reported (Rojas et al. 2002). ORFs 12 and 13 show sequence similarity to a transcriptional regulator in Pseudomonas aeruginosa and a primase in Aquifex aeollicus, respectively. Other ORFs in this region do not show any significant similarity to other proteins in the databases.

Table 1. Open reading frames (ORF) found in regions inserted within or flanking the Erwinia chrysanthemi hrp/hrc cluster and their similarity with proteins in other organisms

\begin{tabular}{|c|c|c|c|c|}
\hline ORF ID & Predicted protein size (aa) & Homolog & Accession no. & BLASTP E value \\
\hline ORF1 & 133 & Hypothetical protein, Mesorhizobium loti & NP_103170 & $4 \mathrm{e}^{-22}$ \\
\hline ORF2 & 146 & None & $\ldots$ & $\ldots$ \\
\hline ORF3 & 195 & None & $\begin{array}{ll}\cdots \\
\cdots\end{array}$ & $\cdots$ \\
\hline ORF4 & 436 & Lytic murein transglycosylase, Xanthomonas axonopodis pv. citri & NP_644735 & $1 \mathrm{e}^{-88}$ \\
\hline ORF5 & 411 & $\mathrm{ABC}$ transporter, Salmonella typhimurium & NP_459371 & $\mathrm{e}^{-136}$ \\
\hline ORF6 & 655 & Methyl accepting chemotactic protein, Yersinia pestis & NP_407489 & $6 \mathrm{e}^{-76}$ \\
\hline ORF7 & 278 & Putative permease of $\mathrm{ABC}$ transporter, $Y$. pestis & NP_668714 & $5 e^{-65}$ \\
\hline ORF8 & 424 & Putative permease of ABC transporter, Y. pestis & NP_668713 & $2 \mathrm{e}^{-143}$ \\
\hline ORF9 & 377 & Putative transport system periplasmic protein, $Y$. pestis & NP_406351 & $\mathrm{e}^{-137}$ \\
\hline ORF10 & 161 (partial) & AttK, Agrobacterium tumefaciens, partial sequence & AAL 13073 & $8 \mathrm{e}^{-54}$ \\
\hline ORF11 & 111 & None & $\ldots$ & $\ldots$ \\
\hline ORF12 & 120 & Transcriptional regulator, Pseudomonas aeruginosa & NP_248738 & $1 \mathrm{e}^{-11}$ \\
\hline ORF13 & 509 & DNA primase, Aquifex aeolicus & NP_214030 & $1 \mathrm{e}^{-21}$ \\
\hline ORF14 & 248 & None & $\ldots$ & $\ldots$ \\
\hline ORF15 & 211 & None & $\ldots$ & $\ldots$ \\
\hline
\end{tabular}
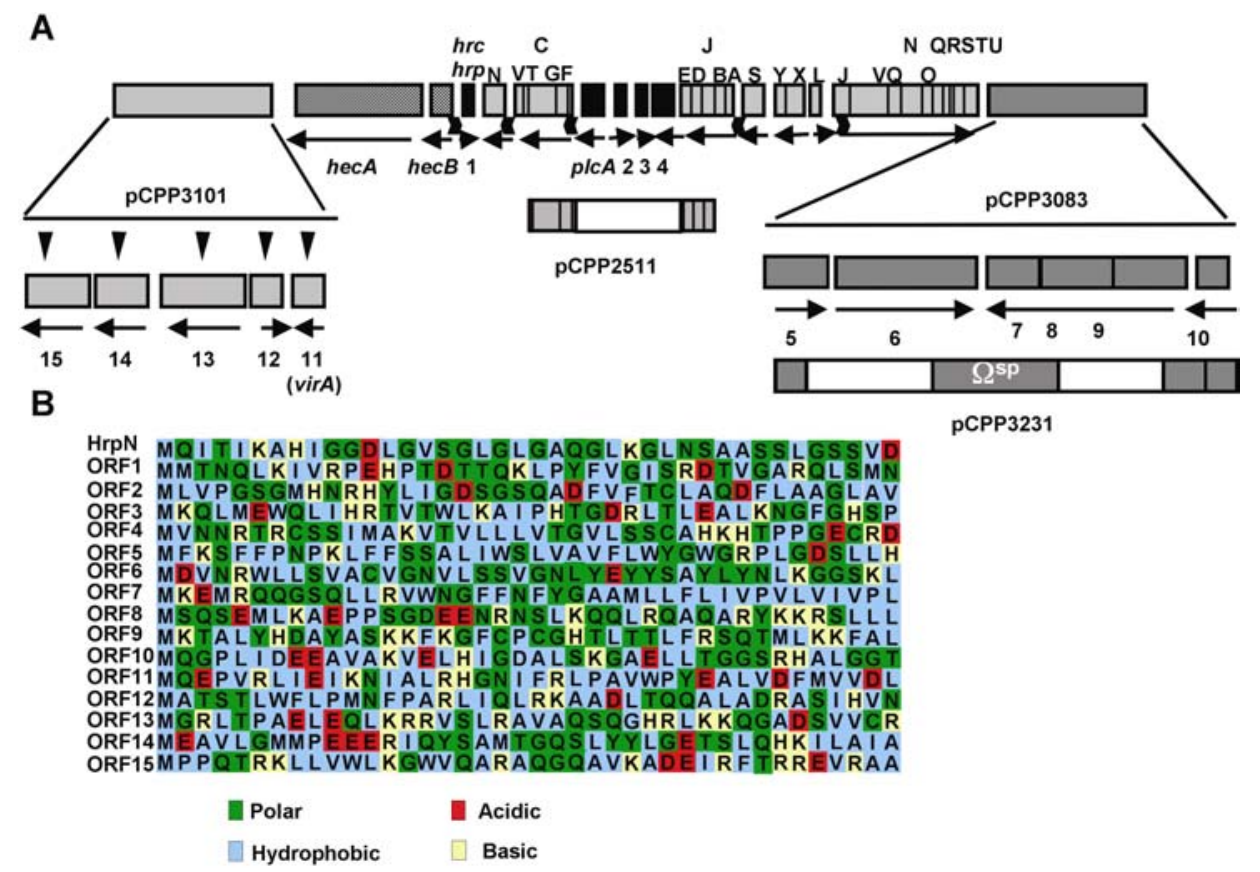

Fig. 1. Erwinia chrysanthemi $h r p / h r c$ cluster and flanking regions. A, The $h r p / h r c$ gene organization is depicted with line arrows representing putative transcription units and small block arrows indicating predicted HrpL-regulated promoters (note that the hrpJ operon is $10 \mathrm{~kb}$ ). Gray boxes represent open reading frames (ORFs) within the $h r p / h r c$ gene cluster. Numbers below boxes indicate ORF designations. Plasmids pCPP3101 and pCPP3083 were used to sequence the flanking regions beyond hecA and $h r c U$, respectively, and the ORFs found are shown with their respective direction of transcription in expanded views of the region. Triangles on ORFs 11 to 15 indicate Mu dII1734 phage insertions that were introduced into the chromosome of $E$. chrysanthemi. Plasmid pCPP2511 was used to create the $\Delta$ plcA -ORF4 deletion mutant CUCPB5097, and plasmid pCPP3231 was used to create the deletion mutant CUCPB5137 encompassing ORFs 5 to 9. B, Sequence of the N-proximal 40 amino acids in HrpN and in ORFs located in the regions that interrupt or flank the hrp/hrc gene cluster. 
virA (ORF11) is the only gene

in the regions that interrupt or flank

the $E$. chrysanthemi hrp/hrc gene cluster

that has a major virulence phenotype.

To determine whether any genes, other than hecA or hecB, that are located in regions that interrupt or flank the hrp/hrc gene cluster play a role in virulence, we constructed strains containing either deletions of several genes or insertions in individual genes in E. chrysanthemi CUCPB5047 (Fig. 1A). We introduced these mutations into CUCPB5047 because it is a $\Delta($ pelA/pelE $) \Delta($ pelB/pelC $):: 28 \mathrm{bp} \Delta($ pelX $) \Delta 4 \mathrm{bp}$ pehX $:: \Omega^{\mathrm{Cm}}$ derivative of AC4150 (Alfano et al. 1995). The reduced maceration capacity of CUCPB5047 favors the detection of subtle virulence phenotypes, as does the use of witloof chicory as a test host plant (Beaulieu et al. 1993). Mutants initially were screened for reduced virulence in chicory leaves using pairwise comparisons of each mutant and its CUCPB5047 parent (Fig. 2). Only CUCPB5356 (ORF11::Mu dII1734) showed a significant reduction in virulence and, consequently, ORF11 is being designated virA. Statistical analysis ( $t$ test) of lesions in witloof chicory leaves showed no significant difference in virulence between other mutant strains and CUCPB5047 ( $P$ values $\geq 0.479)$.

CUCPB5356 and CUCPB5047 showed the same growth in King's B medium (data not shown). pCPP3134, which carries PCR-subcloned virA in pBluescript $\mathrm{SK}$-, was electroporated into CUCPB5356. CUCPB5047, CUCPB5356, and CUCPB5356(pCPP3314) were tested for virulence in chicory leaves and potato tuber slices. Representative results reveal that virA mutation also reduces the virulence of CUCPB5047 in potato tuber slices and that complementation with pCPP3314 restores virulence in both chicory and potato (Fig. 3A). Quantitative assays with chicory confirmed that pCPP3314 restores the virulence of CUCPB5356 to nearly the same level as the parental strain CUCPB5047 (Fig. 3C). Axenically grown Nicotiana seedlings are a third host that often is used in virulence assays involving soft-rot Erwinia spp. (Pirhonen et al. 1991). Because of the weak virulence in N. clevelandii seedlings of CUCPB5047, we marker exchanged the virA::Mu dII1734 mutation into wild-type strain AC4150 to assess the virulence cost of virA mutation in $N$. clevelandii seedlings (Fig. 3B). The resulting mutant, CUCPB5339, was strongly reduced in virulence unless carrying the complementing plasmid pCPP3134.

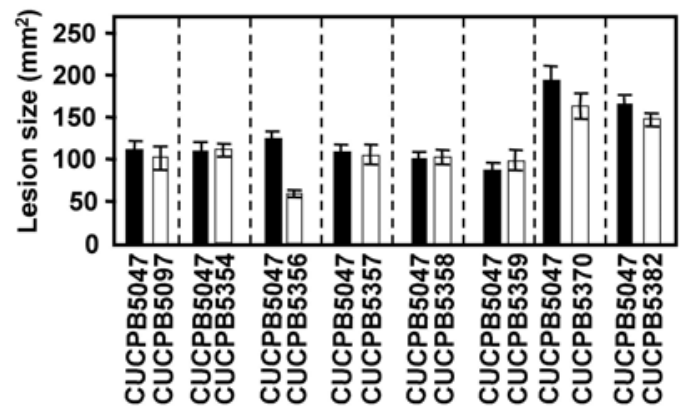

Fig. 2. Relative virulence in witloof chicory leaves of Erwinia chrysanthemi CUCPB5047 and mutant derivatives deficient in open reading frames that are between $h r p F$ and $h r p E$ or flanking hecA and $h r c U$. Witloof chicory leaves were inoculated in 20 replicates with bacterial strains at $1 \times 10^{8} \mathrm{CFU} / \mathrm{ml}$ and incubated in a moist chamber for $48 \mathrm{~h}$. Length and width of the lesions were measured, and mean lesion area was plotted. Error bars indicate standard error. Each mutant was independently compared with CUCPB5047.

\section{E. chrysanthemi can translocate AvrPto-Cya} into $N$. benthamiana cells in an Hrp-dependent manner, but virA is not activated by HrpL or HrpS, and $\operatorname{Vir} A_{(1-61)}$-Cya is not translocated.

Although virA is not preceded by a recognizable Hrp promoter, and the N-terminal region of the predicted VirA protein does not have amino-acid patterns associated with TTSS substrates, the possibility remained that VirA is a Hrp effector protein. In P. syringae, some genes in the Hrp regulon are not

A

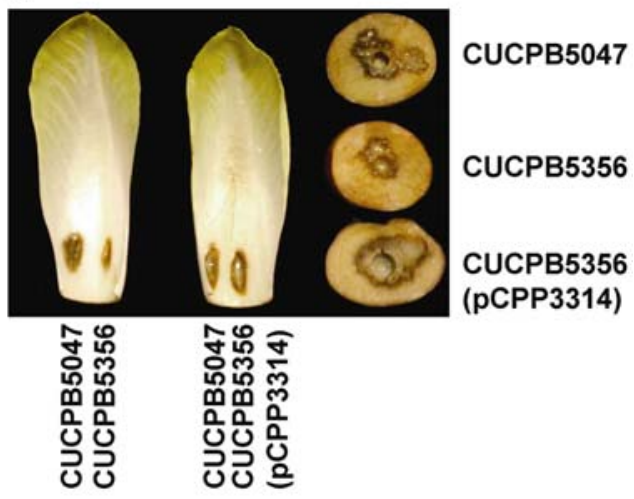

B

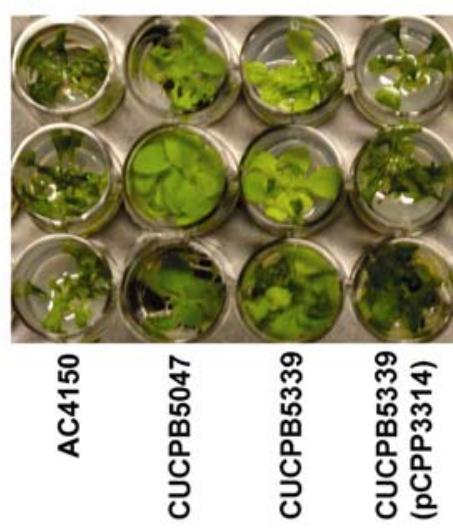

C

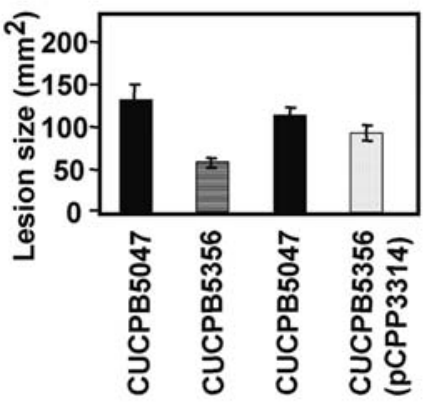

Strains

Fig. 3. Virulence phenotypes in witloof chicory leaves, potato tuber slices, and Nicotiana clevelandii seedlings of Erwinia chrysanthemi virA (open reading frame 11) mutants. A, Representative macerated lesions produced in chicory leaves and potato by CUCPB5047, CUCPB5356, and CUCPB5356(pCPP3314). The photograph was taken $48 \mathrm{~h}$ after inoculation. B, Replicate axenically grown $N$. clevelandii seedlings drop inoculated with AC4150, CUCPB5047, CUCPB5339, and CUCPB5339(pCPP3314). The photograph was taken $48 \mathrm{~h}$ after inoculation. C, Quantitative analysis of the virulence in chicory leaves of CUCPB5047, CUCPB5356, and CUCPB5356(pCPP3314). Strains were grown in King's B medium until optical density at $600 \mathrm{~nm}$ reached 0.7 . 
preceded by Hrp promoters (Fouts et al. 2002), and at least one protein that is translocated into plant cells by the Hrp TTSS lacks diagnostic features associated with TTSS substrates (Schechter et al. 2004). Therefore, we experimentally questioned whether virA expression is dependent upon HrpL or HrpS and whether VirA can be translocated into plant cells by the E. chrysanthemi Hrp TTSS.

We previously had shown that the E. chrysanthemi EC16 $h r p N$ gene is expressed in King's medium B, but it is not expressed in $h r p L$ or $h r p S$ mutants (Ham et al. 2004). To determine if virA is part of the Hrp regulon, we used reverse-transcriptase polymerase chain reaction (RT-PCR) and primers for internal fragments of $h r p N$ and virA to investigate virA expression levels in $E$. chrysanthemi strains that were either wild type (AC4150), or deficient in hrpL (CUCPB5118) or hrpS (CUCPB5360). The 169-bp RT-PCR product from virA transcripts was detected in the wild-type strain as well as the $h r p L$ and hrpS mutant strains (Fig. 4). In the same reaction, however, the 326-bp RT-PCR product from $h r p N$ transcripts was detected only in the wild-type strain but not in the $h r p L$ or hrpS mutant strains, which is consistent with the previous report that $h r p N$ expression is dependent on $h r p L$ and $h r p S$.

The E. chrysanthemi EC16 hrp/hrc gene cluster, heterologously expressed in Escherichia coli, previously had been shown to direct TTSS-dependent secretion of the $P$. syringae AvrPto effector (Ham et al. 1998). Here, we addressed the further question of whether the native Erwinia chrysanthemi Hrp system was capable of translocating AvrPto into plant cells. We used E. chrysanthemi CUCPB5006 because it carries deletions affecting the production of the four major pectate lyase isozymes that are responsible for much of the macerating activity of the parental strain (He and Collmer 1990), and the associated cell killing likely would interfere with the translocation assays. Translocation was assayed using an AvrPto-Cya fusion and $N$. benthamiana plants, as described (Schechter et al. 2004). The assay is based on the ability of Cya (Bordetella pertussis adenylate cyclase) to produce cAMP in a calmodulin-dependent manner in eukaryotic cells (CasperLindley et al. 2002; Sory and Cornelis 1994). N. benthamiana leaf tissue inoculated with CUCPB5006 expressing AvrPtoCya produced significant levels of cAMP (Fig. 5). In contrast, no cAMP was produced in leaf tissue inoculated with CUCPB5038, an hrcT mutant derivative of CUCPB5006, when expressing AvrPto-Cya.

TTSS targeting signals are present in the N-terminal region of TTSS substrates (Lloyd et al. 2001; Ramamurthi and Schneewind 2002), and Cya reporter fusions involving the first approximately 50 amino acids of phytopathogen TTSS substrates have been shown sufficient to direct translocation into plant cells (Casper-Lindley et al. 2002; Schechter et al. in

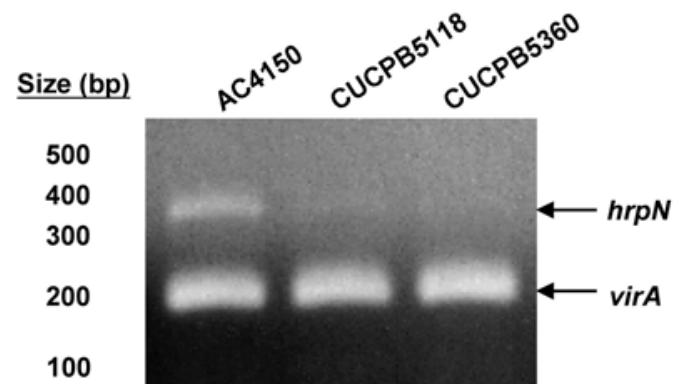

Fig. 4. Expression of virA is independent of HrpL and HrpS. AC4150, CUCPB5118 $\left(h r p L:: \Omega \mathrm{Cm}^{\mathrm{r}}\right)$, and CUCPB5360 $\left(h r p S:: \Omega \mathrm{Cm}^{\mathrm{r}}\right)$ strains were grown in King's B medium until optical density at $600 \mathrm{~nm}$ reached 0.7 . Total RNA was isolated and analyzed by reverse-transcriptase polymerase chain reaction using primer pairs that amplified products of 169 and 326 bp from virA and $h r p N$ transcripts, respectively. press). We were unable to construct a fusion of the full-length VirA to Cya because of apparent toxicity to Escherichia coli. Consequently, we constructed and tested VirA $\mathrm{A}_{(1-61)}-\mathrm{Cya}$. The construct directed the production of cAMP in E. coli lysates supplemented with calmodulin (data not shown), but it failed to produce cAMP in $N$. benthamiana tissue inoculated with CUCPB5006 (Fig. 5). Thus, VirA does not appear to be a substrate for the Erwinia chrysanthemi Hrp TTSS.

\section{DISCUSSION}

To better understand the function of the Hrp system in $E$. chrysanthemi, we searched for genes that encode candidate Hrp effectors or have any virulence phenotype in a 44-kb region of the strain EC16 genome that is centered on the $h r p / h r c$ cluster. Our findings highlight several unusual features of the E. chrysanthemi Hrp system: no candidate effector genes are evident in the entire region and, other than the previously characterized hecA and hecB genes (Rojas et al. 2002), we have found virA (ORF11) to be the only gene flanking the $h r p / h r c$ cluster that has a major virulence phenotype. These observations and other features of the Hrp region warrant further discussion.

There is considerable evidence that the Hrp systems of various plant-pathogenic bacteria can deliver effector proteins into plant cells (Cornelis and Van Gijsegem 2000). The E. chrysanthemi Hrp system functioning heterologously in Escherichia coli can secrete the P. syringae AvrB and AvrPto effectors and also elicit an AvrB-dependent HR in N. clevelandii (Ham et al. 1998). Given the evidence that AvrB acts within plant cells in HR elicitation (Gopalan et al. 1996; Leister et al. 1996; Wu et al. 2003), it appears that the Erwinia chrysanthemi Hrp system is like other Hrp systems in being capable of injecting virulence proteins into plant cells. Here we have shown that $E$. chrysanthemi itself is capable of translocating the model effector AvrPto into plant cells in a TTSS-dependent manner. This experimental confirmation that the native E. chrysanthemi Hrp system is active in planta leaves more puzzling our failure to find any TTSS effector genes in the region of the hrp/hrc cluster, and we are left with the possibility that effector genes may be located elsewhere in the genome.

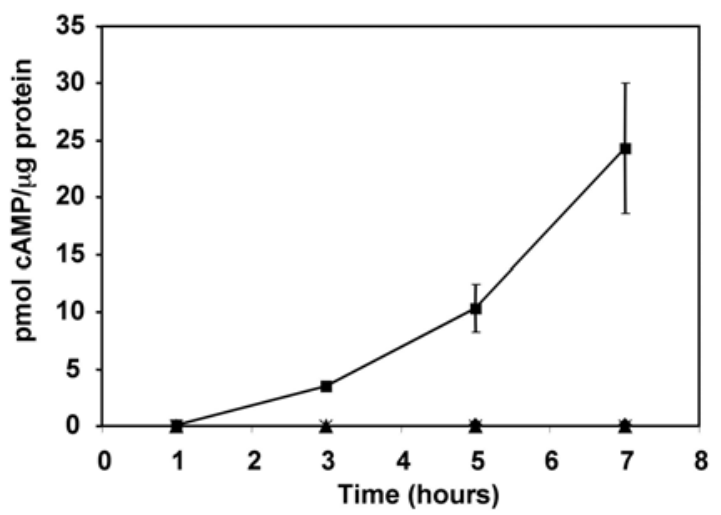

Fig. 5. Time course of cAMP accumulation in Nicotiana benthamiana leaves following inoculation with Erwinia chrysanthemi CUCPB5006 expressing AvrPto-Cya and VirA $\mathrm{A}_{(1-61)}-\mathrm{Cya}$. Bacteria (optical density at 600 $\mathrm{nm}=0.3$ ) were infiltrated with a blunt syringe into $N$. benthamiana leaf tissue and, at the indicated times, samples of the inoculated tissues were assayed for cAMP accumulation. cAMP was quantified in triplicate for each sample, and the standard deviations are indicated by error bars. The experiment was repeated twice with similar results. The strains tested were CUCPB5006 ( $\triangle$ pelABCE) carrying pCPP3221 (AvrPto-Cya) (squares), CUCPB5038 ( $h r c T:: T n 10-$ mini-Km derivative of CUCPB5006) carrying pCPP3221 (AvrPto-Cya) (triangles), and CUCPB5006 carrying pCPP3381 (VirA $(1-61)$-Cya) (crosses). 
We have shown that the E. chrysanthemi hrp/hrc cluster is similar to other group I clusters in its gene order and the presence of the HrpL alternative sigma factor and Hrp box promoter sequences. However, we also found that it is unusual among hrp/hrc clusters in several aspects. The first unusual feature is the presence of three unique ORFs ( $p l c A$, ORF2, and ORF3) inside the $h r p / h r c$ gene cluster (Kim et al. 1998 b) that do not appear to be functionally related to the Hrp system. plcA encodes a phospholipase $\mathrm{C}$ that has been reported to carry an $\mathrm{N}$-terminal signal peptide and to be secreted in culture by E. chrysanthemi and Escherichia coli DH5 $\alpha$ transformants (Keen et al. 1992). A fourth ORF in this region encodes a putative lytic transglycosylase (lysozymelike protein). Such proteins commonly are associated with hrp/hrc clusters, contain a peptidoglycan binding domain, and have been suggested to be required for remodeling of the periplasmic peptidoglycan during the assembly of the type III secretion apparatus (Alfano et al. 2000; Noel et al. 2002; Zhu et al. 2000). Similar to the observations with the putative lysozyme-like $\mathrm{HpaH}$ in $X$. campestris pv. vesicatoria (Noel et al. 2002), mutations in Erwinia chrysanthemi ORF4 have no effect on virulence.

Comparison of the regions flanking the hrp/hrc clusters of E. chrysanthemi and E. carotovora subsp. atroseptica is interesting because of the notable absence of genes encoding Hrpsecreted proteins in E. chrysanthemi. That is, in the left flank- ing region, both species have hecA and hecB homologs, but only E. carotovora. subsp. atroseptica has $h r p W$ and $d s p E$ (Bell et al. 2002). In the right flanking region, neither species has apparent effector genes, but both have genes associated with ABC transporters and opine catabolism.

In other plant-pathogenic enterobacteria, virulence-associated genes not related with Hrp secretion also have been found in the $h r p / h r c$ flanking regions. One is $r l s A$, which encodes a regulator of levan production in E. amylovora (Zhang and Geider 1999). In E. chrysanthemi, only virA (ORF11) was found to make a significant contribution to E. chrysanthemi virulence. The predicted VirA protein sequence yields no clue to function, and its mechanism of action remains to be elucidated. Our observations that virA expression is independent of HrpL and HrpS and that a $\operatorname{VirA}_{(1-61)}-$ Cya hybrid is not translocated into plant cells by E. chrysanthemi argues against VirA functioning in association with the Hrp system. In this regard, it is worth noting that virA mutants are more impaired in virulence than the corresponding $h r c T$ mutants in each of the virulence assays that we used (Bauer et al. 1994; Rojas et al. 2002). This provides further evidence for an action of VirA that is independent of HrcT and other components of the E. chrysanthemi TTSS.

Mutations in the other genes located in the hrp/hrc flanking regions showed no phenotype in virulence assays. However, microarray analysis in E. chrysanthemi strain 3937 revealed that

Table 2. Bacterial strains and plasmids used in this work

\begin{tabular}{|c|c|c|}
\hline Designation & Relevant characteristics $^{\mathbf{a}}$ & Reference or source \\
\hline \multicolumn{3}{|l|}{ Escherichia coli } \\
\hline MC4100 & FaraD1394(lacIPOZYA-argF)U169 rpsL thi & Casadaban and Cohen 1979 \\
\hline POII1734 & MC1040 (Mu cts) with Mu dII1734 lac ${ }^{+}$ & Castilho et al. 1984 \\
\hline \multicolumn{3}{|c|}{ Erwinia chrysanthemi } \\
\hline AC4150 & Spontaneous $\mathrm{Nal}^{\mathrm{R}}$ derivative of wild-type strain $\mathrm{EC} 16$ & Chatterjee et al. 1983 \\
\hline CUCPB5006 & $\Delta($ pelA/pelE $) \Delta($ pelB/pelC $):: 28 \mathrm{bp}$ derivative of $\mathrm{AC} 4150$ & He and Collmer 1990 \\
\hline CUCPB5038 & hrcT::Tn10-mini-Km derivative of CUCPB5006 & Bauer et al. 1994 \\
\hline CUCPB5047 & $\Delta($ pelA/pelE $) \Delta($ pelB/pelC $):: 28 \mathrm{bp} \Delta($ pelX $) \Delta 4 \mathrm{bp}$ pehX: $\Omega^{\mathrm{Cm}}$ & Alfano et al. 1995 \\
\hline CUCPB5093 & $\Delta$ plcA-ORF4::nptII-sacB-sacR derivative of CUCPB5047 & This work \\
\hline CUCPB5097 & $\Delta p l c A$-ORF4::28-bp derivative of CUCPB5093 & This work \\
\hline CUCPB5118 & $h r p L:: \Omega \mathrm{Cm}^{\mathrm{r}}$ derivative of AC4150 & This work \\
\hline CUCPB5354 & $\Delta$ ORF5-ORF9 replaced by $\Omega^{\mathrm{Sp}}$ cassette derivative of CUCPB 5047 & This work \\
\hline CUCPB5356 & virA::Mu dII1734 derivative of CUCPB5047 & This work \\
\hline CUCPB5357 & ORF12::Mu dII1734 derivative of CUCPB5047 & This work \\
\hline CUCPB5358 & ORF14::Mu dII1734 derivative of CUCPB5047 & This work \\
\hline CUCPB5359 & ORF15::Mu dII1734 derivative of CUCPB5047 & This work \\
\hline CUCPB5370 & ORF13::Mu dII1734 derivative of CUCPB5047 & This work \\
\hline CUCPB5382 & ORF1:: $\Omega^{\mathrm{Sp}}$ derivative of CUCPB5047 & This work \\
\hline CUCPB5339 & virA::Mu dII1734 derivative of AC4150 & This work \\
\hline \multicolumn{3}{|c|}{ Cosmids and plasmids } \\
\hline pCPP2156 & pCPP19 carrying Erwinia chrysanthemi hrp/hrc genes and $10 \mathrm{~kb}$ of the right flanking region, $\mathrm{Sp}^{\mathrm{r}}$ & Ham et al. 1998 \\
\hline pCPP5329 & Cosmid clone containing genes at the left flanking region of the $E$. chrysanthemi $h r p / h r c$ genes & This work \\
\hline pCPP2354 & 3.1-kb SalI/BamHI fragment of pCPP1221 in pWSK29 that harbors $h r p F, h r p G$, and $h r c C$ & Kim et al. $1998 \mathrm{a}$ \\
\hline pCPP2359 & 7.5-kb BamHI/BgIII clone in pUC18 that contains part of $h r p C$ operon, plcA, ORF2, ORF3, ORF4 & This work \\
\hline pCPP2360 & 4.3-kb BamHI/BgIII clone in pUC18 that contains $h r p A$ operon & This work \\
\hline pCPP2504 & 6.1-kb BglII clone in pBluescriptSK+ that contains $h r p A$ to $h r p Y$ & This work \\
\hline pCPP2505 & $10.5-\mathrm{kb} B g l I I$ clone in pBluescriptSK+ that contains $h r p \mathrm{~L}$ to $h r c R$. & This work \\
\hline pCPP2511 & $\Delta p l c A-O R F 4$ construct & This work \\
\hline pCPP5112 & $\Delta p l c A-\mathrm{ORF} 4$ construct & This work \\
\hline pCPP2513 & $1.8-\mathrm{kb}$ SacII clone in pUC18 that contains $h r c J, h r p D$, and $h r p E$ & This work \\
\hline pCPP3083 & $\begin{array}{l}\text { BglII subclone containing } h r c R, h r c S, h r c T, h r c U \text {, and 10-kb right flanking region in pBluescript } \\
\text { SK- }\end{array}$ & This work \\
\hline рCPP3040 & 4.8-kb EcoRV fragment from pCPP3083 in pBluescript SK- & This work \\
\hline рСРP3099 & 4-kb KpnI fragment from pCPP3083 in pBluescript SK- & This work \\
\hline pCPP3094 & 30-kb NotI fragment containing genes at the left flanking region in pBluescriptSK- beyond hecA & This work \\
\hline pCPP3101 & 7-kb PstI fragment from pCPP3094 in pBluescriptSK- & This work \\
\hline pCPP3231 & $\triangle \mathrm{ORF} 5-\mathrm{ORF} 9$ construct in pUCP24 & This work \\
\hline pCPP3234 & pVLT35 containing Gateway Reading Frame B cassette & Schechter et al. 2004 \\
\hline pCPP3287 & $\mathrm{ORF} 1:: \Omega^{\mathrm{Sp}}$ in pBluescriptSK- & This work \\
\hline pCPP3314 & ORF11 in pBluescriptSK- & This work \\
\hline pCPP3381 & Codons $1-61$ of virA fused with cya in pCPP3234 & This work \\
\hline
\end{tabular}

${ }^{\mathrm{a}} \mathrm{ORF}=$ open reading frame, $\mathrm{Km}=$ kanamycin, $\mathrm{Cm}=$ chloramphenicol, $\mathrm{Sp}=$ spectinomycin. 
several $\mathrm{ABC}$ transporters are upregulated during infection of African violet (Okinaka et al. 2002), and screening with reporter gene fusions revealed methyl-accepting chemotactic proteins and transcriptional regulators to be induced in witloof chicory disks (Aguilar et al. 2002). These observations suggest that the ORFs found in the flanking regions of the hrp/hrc cluster might contribute to virulence by allowing bacterial survival in planta either by conferring resistance to antibiotic peptides, as shown before with the Sap operon, or by aiding nutrient uptake (Lopez-Solanilla et al. 1998). Although the mutants we constructed had no phenotype in our virulence assays, it is possible that they have a function in virulence that is masked by redundancy.

Whether the hrp/hrc genes in E. chrysanthemi are part of a pathogenicity island is an open question. The average $\mathrm{G}+\mathrm{C}$ contents for the ORFs interrupting the hrp/hrc gene cluster and for the ORFs located in the right flanking region are 55.83 and $56.48 \%$, respectively, which is similar to the $\mathrm{G}+\mathrm{C}$ content for the rest of the genome (55 to $57 \%$ ). The average $\mathrm{G}+\mathrm{C}$ content for the $h r p / h r c$ genes and the left flanking region is slightly higher (58\%). Strikingly, the $\mathrm{G}+\mathrm{C}$ content for virA is $38 \%$. Although transposon and IS elements were observed in partial sequences of the region beyond ORF15, no tRNA sequences were observed (data not shown). In summary, the regions flanking the hrp/hrc gene cluster of E. chrysanthemi EC16 differ from that of host-specific pathogens in lacking any apparent TTSS substrate genes and, instead, encoding the functionally disparate virulence genes hecA and virA. This is consistent with the apparent role of the Hrp TTSS as just one of many virulence systems contributing to the ability of E. chrysanthemi to attack a broad range of plants.

\section{MATERIALS AND METHODS}

\section{Bacterial strains, culture conditions, and DNA manipulation techniques.}

Bacterial strains and plasmids are listed in Table 2. Escherichia coli strains were grown at $37^{\circ} \mathrm{C}$ in LM medium supplemented with ampicillin (Ap) at $100 \mu \mathrm{g} / \mathrm{ml}$ or spectinomycin (Sp) at $25 \mu \mathrm{g} / \mathrm{ml}$. Erwinia chrysanthemi strains were grown at $30^{\circ} \mathrm{C}$ in King's B medium supplemented with kanamycin $(\mathrm{Km})$ at $50 \mu \mathrm{g} / \mathrm{ml}$ or chloramphenicol $(\mathrm{Cm})$ at $20 \mu \mathrm{g} / \mathrm{ml}$. Plasmids and cosmids were isolated from Escherichia coli DH5 $\alpha$ following standard procedures (King et al. 1954; Sambrook et al. 1989). DNA fragments for cloning were purified using Prep-a-Gene (Bio-Rad, Richmond, CA, U.S.A.) and ligated to pBluescriptSK- (Stratagene, LaJolla, CA, U.S.A.), pBluescriptSK+ (Stratagene), pUC18 (Fermentas, Hanover, MD), or pUCP24 (Schweizer 1991).

\section{Sequencing of $\mathbf{h r p} / \mathrm{hrc}$ genes.}

Sequences of the $h r p N$ and $h r p C$ operons have been reported previously (Bauer et al. 1995; Kim et al. 1998b). Plasmid pCPP2359 was used to sequence from plcA to the $3^{\prime}$ end of ORF4, pCPP2504 was used to sequence the rest of ORF4, the entire $h r p A$ operon and $h r p Y$, and pCPP2505 was used to sequence the region from $h r p X$ to $h r c R$. Sequencing from these plasmids was initiated using universal and reverse primers followed by primer walking. DNA sequencing was performed with an ABI 3700 DNA sequencer (Applied Biosystems, Foster City, CA, U.S.A.) at the Cornell University BioResource Center. Sequences were assembled using SEQMAN 5.03 (DNAStar, Madison, WI, U.S.A.), and ORFs were identified using MapDraw (DNAStar). Assembled sequences were used to search the GenBank nonredundant database using the BLASTX program (Altschul et al. 1990). The accession number for the sequence is AY169276.
Sequencing of regions flanking hrp/hrc genes.

Plasmid pCPP3083 containing $h r c R$ to $h r c U$ and the right flanking region of the $h r p / h r c$ genes was subcloned into plasmids pCPP3040 and pCPP3099. pCPP3040 was sequenced using universal and reverse primers followed by primer walking. pCPP3094, derived from cosmid pCPP5329, was subcloned into pCPP3101. pCPP3099 and pCPP3101 were electroporated into Escherichia coli POII1734, which contains phage Mu dII1734 (Castilho et al. 1984). Phage insertions in the plasmids were transduced into E. coli MC4100 following standard procedures (Miller 1992). Plasmids were isolated from transductants, and different insertions were chosen to sequence outwards from the phage using primers 5'CGCTTTCGGGTTTTTCGTG-3' and 5'-ATCCCGAATAATC CAATGTCCTC-3'; gaps in contigs were filled with custommade primers and sequences were assembled and analyzed as described before. The accession numbers for the sequences are AY169277 (left side beyond hecA) and AY169278 (right side beyond $h r c U$ ).

\section{Deletion of the intergenic region between the $h r p A$ and $h r p C$ operons.}

pCPP2360, containing the hrpA operon, was digested with SacII, and a 1.8-kb SacII fragment was blunt-ended and ligated to SmaI-digested pUC18 to create pCPP2513. pCPP2354, containing $h r p F, h r p G$, and $h r p C$, was digested with $K p n I$ and $S a c I$ and the 3.1-kb fragment was isolated and ligated to KpnI/SacI-digested pCPP2513 to generate pCPP2511. The latter plasmid was digested with Kpn1, and the protruding $3^{\prime}$ ends were blunted and ligated with the nptIIsacB-sacR cassette from pUM24Cm, which contains the pUM24-derived cassette in pPR328 (Quigley and Reeves 1987; Ried and Collmer 1987). This produced pCPP2512, which was used to mutate Erwinia chrysanthemi CUCPB5047 by marker exchange to produce CUCPB5093. The nptII-sacBsacR cassette then was removed from CUCPB5093 by marker eviction employing pCPP2511 (Ried and Collmer 1987), which produced CUCPB5097 carrying a 28-bp scar marking the plcA-ORF4 deletion.

\section{Construction of ORF1 mutation.}

Primers 5'-GTTTCTAGATATTAAAACGACAGCC-3', containing an $\mathrm{XbaI}$ site, and 5'-CGACTAGTGTTCCGGCCTGAC AA-3', containing a SpeI site, were designed to amplify $39 \mathrm{bp}$ from the $5^{\prime}$ end of ORF1 and an approximately $2-\mathrm{kb}$ region upstream. Primers 5'-CCACTCGAGAACTGCCCTATTTTGT CG-3', containing an XhoI site, and 5'-AGGGTACCCGCTGG TCGCCGCAA-3', containing a KpnI site, amplified a region that includes bases 59 to 399 in ORF1 and approximately $2 \mathrm{~kb}$ downstream. PCR products were purified with the QIAquick PCR purification kit (Qiagen, Valencia, CA, U.S.A.), digested with the enzyme pair combinations, gel-purified, and cloned into pBluescriptSK-, generating plasmids pBSSK-::ORF1A and pBSSK-::ORF1B, respectively. pBSSK-::ORF1A was digested with $B a m H I$ and ligated to a purified $\Omega^{\mathrm{Sp}}$ cassette. This construct, pBSSK-::ORF1A:: $\Omega^{\mathrm{Sp}}$, was digested with XhoI and $X b a \mathrm{I}$, and the $4-\mathrm{kb}$ fragment was purified and ligated to pBSSK::ORF1B to produce plasmid pCPP3287.

\section{Plasmid construction.}

Plasmid pCPP3314, which carries ORF11, was constructed by PCR amplification. Primers 5'-GTCGAATTCGGGATGA TGCCAA-3' and 5'-CGGCTCGAGATTGAGGCGGAGAT-3', containing EcoRI and XhoI sites, respectively, were used to amplify a 500-bp fragment containing ORF11 and 168 bp 5' of the $3^{\prime}$ end of ORF12. The PCR product was purified with the QIAquick PCR purification kit (Qiagen), digested, gel-puri- 
fied, and ligated to pBluescriptSK- digested with EcoRI and XhoI, generating plasmid pCPP3314. pCPP3381, which expresses the first 61 amino acids of VirA fused to Cya VirA $_{(1-}$ 61)-Cya), was created using Gateway cloning technology (Invitrogen, Carlsbad, CA, U.S.A.). First, the first 61 codons of virA were amplified by PCR using primers 5'-CACCATGCAAGAGCCAGTAAGATTAATTG-3' and 5'-TAATA TTAGACCAGCCTTATGACCAG- ${ }^{\prime}$, and this fragment was cloned into the $\mathrm{pENTR/SD/D-TOPO}$ entry vector according to the manufacturer's instructions. pCPP3381 then was created by a site-specific recombination reaction (or LR reaction) between the virA61 entry vector and pCPP3234 (Schechter et al., in press).

\section{Deletion of genes located in the right flanking region.}

A 1.9-kb KpnI-EcoRI fragment spanning from $h r c R$ to part of ORF5 was isolated from pCPP3083 and cloned into pUCP24. A 2-kb region from ORF7 to ORF9 was cloned into pBluescriptSK- by PCR amplification using primers $5^{\prime}-\mathrm{CC}$ ACTAGTCCGTCTCATCAGGCACATCTT-3' and 5'-GTTCT AGACGCCGACGGTGGTAGG-3', containing SpeI and XbaI sites, respectively. pBSSK-::ORF7-ORF9 was digested with BamHI and ligated to a purified $\Omega^{\mathrm{Sp}}$ cassette. This construct, pBSSK-::ORF7-ORF9:: $\Omega^{\mathrm{Sp}}$, was digested with XbaI and SmaI, and the $4-\mathrm{kb}$ fragment was isolated and ligated to pUCP24::hrcR-ORF5 to create pCPP3231.

\section{Mutagenesis of $E$. chrysanthemi.}

Plasmids containing phage insertions in ORFs 10, 11, 12, 13, and 14 and the plasmids pCPP3231, pCPP2511, and pCPP3287 were electroporated into $\Delta($ pelA/pelE $) \Delta($ pelB/pelC $)::$ 28bp $\Delta\left(\right.$ pelX) $\Delta 4$ bp pehX:: $\Omega^{\mathrm{Cm}}$ mutant CUCPB5047. Transformants obtained after electroporation were used for marker exchange following standard procedures (Roeder and Collmer 1985). CUCPB5118 was constructed by introducing the $h r p L:: \Omega \mathrm{Cm}^{\mathrm{r}}$ mutation into AC4150 as previously described (Ham et al. 2004). Mutant constructs were confirmed by DNA gel blot analysis.

\section{RT-PCR analysis.}

E. chrysanthemi AC4150, CUCPB5118, and CUCPB5360 were grown in King's B medium until an optical density at $600 \mathrm{~nm}\left(\mathrm{OD}_{600}\right)$ reached 0.7. Total RNA from $100 \mu \mathrm{l}$ of culture was extracted and eluted in $30 \mu \mathrm{l}$ of diethylpyrocarbonatetreated $\mathrm{H}_{2} \mathrm{O}$ with the RNeasy Mini Kit (Qiagen). Then, $2 \mu \mathrm{l}$ of each RNA sample was further treated with Dnase I, amplification grade (Invitrogen), to eliminate remaining DNA in $10 \mu \mathrm{l}$ of total reaction volume. After $20 \mathrm{~min}$ of incubation, Dnase I was inactivated with $1 \mu \mathrm{l}$ of $25 \mathrm{mM}$ EDTA and heat treatment $\left(70^{\circ} \mathrm{C}, 10 \mathrm{~min}\right)$. Of a total $11 \mu \mathrm{l}$ of reaction mixture, $1 \mu \mathrm{l}$ was used as the template for RT-PCR. Two primer pairs (5'-TCGC TGGGTTCCAGCGTGGAT-3' and 5'-CATCTGGCTGGCGT TCAGCAT-3' for $h r p N$ and 5'-AGGATCTCATATCGGTCTAT T-3' and 5'-TCATCTGGTCATAAGGCTGGT-3' for virA) were added to the RT-PCR reaction mixture in order to detect $h r p N$ and virA transcripts simultaneously. RT-PCR was performed with Superscript One-Step RT-PCR kit (Invitrogen) following the manufacturer's protocol. The program for RT-PCR was $50^{\circ} \mathrm{C}$ for $30 \mathrm{~min} ; 94^{\circ} \mathrm{C}$ for $2 \mathrm{~min} ; 40$ cycles of $94^{\circ} \mathrm{C}$ for $15 \mathrm{~s}$, $50^{\circ} \mathrm{C}$ for $30 \mathrm{~s}$, and $68^{\circ} \mathrm{C}$ for $40 \mathrm{~s}$; and $72^{\circ} \mathrm{C}$ for $5 \mathrm{~min}$.

\section{Plant assays.}

E. chrysanthemi strains were grown in King's B plates at $30^{\circ} \mathrm{C}$ overnight and resuspended in $5 \mathrm{ml}$ of $10 \mathrm{mM} \mathrm{MgCl}_{2}$ to an $\mathrm{OD}_{600}$ of 0.3 . Witloof chicory leaves and potato tubers were wound inoculated with $50 \mu \mathrm{l}$ of a bacterial suspension containing $1 \times 10^{8} \mathrm{CFU} / \mathrm{ml}$ and incubated in a moist chamber at $30^{\circ} \mathrm{C}$ for $48 \mathrm{~h}$, following previously described procedures (Bauer et al. 1994; López-Solanilla et al. 2001). Because of quantitative variation in the susceptibility of different batches of chicory leaves to $E$. chrysanthemi, assays for the virulence phenotype of any mutant were done in direct comparison with the CUCPB5047 parental strain using the batch available.

Maceration was scored $48 \mathrm{~h}$ after inoculation. Axenically grown $N$. clevelandii seedlings were inoculated by pipetting 50 $\mu \mathrm{l}$ of bacterial suspension to the apical meristem and incubating at $25^{\circ} \mathrm{C}$ (Rojas et al. 2002). Symptoms were photographed $48 \mathrm{~h}$ after inoculation. Assays for Cya-dependent cAMP production in $N$. benthamiana leaves were performed as described previously, except that bacteria were suspended in $5 \mathrm{mM}$ MES, pH 6.5 (Schechter et al. in press). Plants were bagged and incubated at $27^{\circ} \mathrm{C}$ during the course of the experiment.

\section{ACKNOWLEDGMENTS}

This work was supported by the United States Department of Agriculture National Research Initiative Competitive Grants Program grant 9735303-4488 and National Science Foundation grant MCB-9982646. We thank D. L. Coplin for facilities, supplies, and advice in support of the RTPCR analysis and K. Loeffler for photography.

\section{LITERATURE CITED}

Aguilar, I., Poza-Carrion, C., Guio, A., and Rodriguez-Palenzuela, P. 2002. Erwinia chrysanthemi genes specifically induced during infection in chicory leaves. Mol. Plant Pathol. 3:271-275.

Alfano, J. R., Charkowski, A. O., Deng, W.-L., Badel, J. L., PetnickiOcwieja, T., van Dijk, K., and Collmer, A. 2000. The Pseudomonas syringae Hrp pathogenicity island has a tripartite mosaic structure composed of a cluster of type III secretion genes bounded by exchangeable effector and conserved effector loci that contribute to parasitic fitness and pathogenicity in plants. Proc. Natl. Acad. Sci. U.S.A. 97:48564861 .

Alfano, J. R., and Collmer, A. 1997. The type III (Hrp) secretion pathway of plant pathogenic bacteria: trafficking harpins, Avr proteins, and death. J. Bacteriol. 179:5655-5662.

Alfano, J. R., Ham, J. H., and Collmer, A. 1995. Use of Tn5 tac1 to clone a pel gene encoding a highly alkaline, asparagine-rich pectate lyase isozyme from an Erwinia chrysanthemi mutant with deletions affecting the major pectate lyase isozymes. J. Bacteriol. 177:4553-4556.

Altschul, S. F., Gish, W., Miller, W., Myers, E. W., and Lipman, D. J. 1990. Basic local alignment search tool. J. Mol. Biol. 215:403-410.

Barras, F., Van Gijsegem, F., and Chatterjee, A. K. 1994. Extracellular enzymes and pathogenesis of soft-rot Erwinia. Annu. Rev. Phytopathol. 32:201-234.

Bauer, D. W., Bogdanove, A. J., Beer, S. V., and Collmer, A. 1994. Erwinia chrysanthemi hrp genes and their involvement in soft rot pathogenesis and elicitation of the hypersensitive response. Mol. PlantMicrobe Interact. 7:573-581.

Bauer, D. W., Wei, Z.-M., Beer, S. V., and Collmer, A. 1995. Erwinia chrysanthemi harpin $_{\mathrm{Ech}}$ : an elicitor of the hypersensitive response that contributes to soft-rot pathogenesis. Mol. Plant-Microbe Interact. 8:484491.

Beaulieu, C., Boccara, M., and Van Gijsegem, F. 1993. Pathogenic behavior of pectinase-defective Erwinia chrysanthemi mutants on different plants. Mol. Plant-Microbe Interact. 6:197-202.

Bell, K. S., Avrova, A. O., Holeva, M. C., Cardle, L., Morris, W., De Jong, W., Toth, I. K., Waugh, R., Bryan, G. J., and Birch, P. R. 2002. Sample sequencing of a selected region of the genome of Erwinia carotovora subsp. atroseptica reveals candidate phytopathogenicity genes and allows comparison with Escherichia coli. Microbiology 148:1367-1378.

Bogdanove, A. J., Wei, Z.-M., Zhao, L., and Beer, S. V. 1996. Erwinia amylovora secretes harpin via a type III pathway and contains a homolog of yopN of Yersinia spp. J. Bacteriol. 178:1720-1730.

Buell, C. R., Joardar, V., Lindeberg, M., Selengut, J., Paulsen, I. T., Gwinn, M. L., Dodson, R. J., Deboy, R. T., Durkin, A. S., Kolonay, J. F., Madupu, R., Daugherty, S., Brinkac, L., Beanan, M. J., Haft, D. H., Nelson, W. C., Davidsen, T., Liu, J., Yuan, Q., Khouri, H., Fedorova, N., Tran, B., Russell, D., Berry, K., Utterback, T., Vanaken, S. E., Feldblyum, T. V., D’Ascenzo, M., Deng, W.-L., Ramos, A. R., Alfano, J. R., Cartinhour, S., Chatterjee, A. K., Delaney, T. P., Lazarowitz, S. G., Martin, G. B., Schneider, D. J., Tang, X., Bender, C. L., White, O., Fraser, C. M., and Collmer, A. 2003. The complete sequence of the 
Arabidopsis and tomato pathogen Pseudomonas syringae pv. tomato DC3000. Proc. Natl. Acad. Sci. U.S.A. 100:10181-10186.

Casadaban, M. J., and Cohen, S. N. 1979. Lactose genes fused to exogenous promoters in one step using a Mu-lac bacteriophage: in vivo probe for transcriptional control sequences. Proc. Natl. Acad. Sci. U.S.A. 76:4530-3.

Casper-Lindley, C., Dahlbeck, D., Clark, E. T., and Staskawicz, B. J. 2002. Direct biochemical evidence for type III secretion-dependent translocation of the AvrBs2 effector protein into plant cells. Proc. Natl. Acad. Sci. U.S.A. 99:8336-8341.

Castilho, B. A., Olfson, P., and Casadaban, M. J. 1984. Plasmid insertion mutagenesis and lac gene fusion with mini-Mu bacteriophage transposons. J. Bacteriol. 158:488-495.

Chatterjee, A. K., Thurn, K. K., and Feese, D. A. 1983. Tn5 induced mutations in the enterobacterial phytopathogen Erwinia chrysanthemi. Appl. Environ. Microbiol. 45:644-650.

Collmer, A., Lindeberg, M., Petnicki-Ocwieja, T., Schneider, D. J., and Alfano, J. R. 2002. Genomic mining type III secretion system effectors in Pseudomonas syringae yields new picks for all TTSS prospectors. Trends Microbiol. 10:462-469.

Coplin, D. L., Frederick, R. D., Majerczak, D. R., and Tuttle, L. D. 1992. Characterization of a gene cluster that specifies pathogenicity in Erwinia stewartii. Mol. Plant-Microbe Interact. 5:81-88.

Cornelis, G. R., and Van Gijsegem, F. 2000. Assembly and function of type III secretory systems. Annu. Rev. Microbiol. 54:735-774.

Dangl, J. L., and Jones, J. D. 2001. Plant pathogens and integrated defence responses to infection. Nature 411:826-833.

Da Silva, A. C., Ferro, J. A., Reinach, F. C., Farah, C. S., Furlan, L. R., Quaggio, R. B., Monteiro-Vitorello, C. B., Sluys, M. A., Almeida, N. F., Alves, L. M., Do Amaral, A. M., Bertolini, M. C., Camargo, L. E., Camarotte, G., Cannavan, F., Cardozo, J., Chambergo, F., Ciapina, L. P., Cicarelli, R. M., Coutinho, L. L., Cursino-Santos, J. R., El-Dorry, H., Faria, J. B., Ferreira, A. J., Ferreira, R. C., Ferro, M. I., Formighieri, E. F., Franco, M. C., Greggio, C. C., Gruber, A., Katsuyama, A. M., Kishi, L. T., Leite, R. P., Lemos, E. G., Lemos, M. V., Locali, E. C., Machado, M. A., Madeira, A. M., Martinez-Rossi, N. M., Martins, E. C., Meidanis, J., Menck, C. F., Miyaki, C. Y., Moon, D. H., Moreira, L. M., Novo, M. T., Okura, V. K., Oliveira, M. C., Oliveira, V. R., Pereira, H. A., Rossi, A., Sena, J. A., Silva, C., De Souza, R. F., Spinola, L. A. Takita, M. A., Tamura, R. E., Teixeira, E. C., Tezza, R. I., Trindade Dos Santos, M., Truffi, D., Tsai, S. M., White, F. F., Setubal, J. C., and Kitajima, J. P. 2002. Comparison of the genomes of two Xanthomonas pathogens with differing host specificities. Nature 417:459-463.

Deng, W.-L., Rehm, A., Charkowski, A., Rojas, C. M., and Collmer, A 2003. Pseudomonas syringae exchangeable effector loci: sequence diversity in representative pathovars and virulence function in $P$. syringae pv. syringae B728a. J. Bacteriol. 185:2592-2602.

Fouts, D. E., Abramovitch, R. B., Alfano, J. R., Baldo, A. M., Buell, C. R., Cartinhour, S., Chatterjee, A. K., D’Ascenzo, M., Gwinn, M. L., Lazarowitz, S. G., Lin, N.-C., Martin, G. B., Rehm, A. H., Schneider, D. J., van Dijk, K., Tang, X., and Collmer, A. 2002. Genomewide identification of Pseudomonas syringae pv. tomato DC3000 promoters controlled by the HrpL alternative sigma factor. Proc. Natl. Acad. Sci. U.S.A. 99:2275-2280

Fouts, D. E., Badel, J. L., Ramos, A. R., Rapp, R. A., and Collmer, A 2003. A Pseudomonas syringae pv. tomato DC3000 Hrp (type III secretion) deletion mutant expressing the Hrp system of bean pathogen $P$. syringae pv. syringae 61 retains normal host specificity for tomato. Mol. Plant-Microbe Interact. 16:43-52.

Frederick, R. D., Ahmad, M., Majerczak, D. R., Arroyo-Rodriguez, A. S., Manulis, S., and Coplin, D. L. 2001. Genetic organization of the Pantoea stewartii subsp. stewartii hrp gene cluster and sequence analysis of the hrpA, hrpC, hrpN, and wtsE operons. Mol. Plant-Microbe Interact. 14:1213-22.

Galán, J. E., and Collmer, A. 1999. Type III secretion machines: ingenious bacterial devices for protein delivery into host cells. Science 284:13221328

Gopalan, S., Bauer, D. W., Alfano, J. R., Loniello, A. O., He, S. Y., and Collmer, A. 1996. Expression of the Pseudomonas syringae avirulence protein AvrB in plant cells alleviates its dependence on the hypersensitive response and pathogenicity (Hrp) secretion system in eliciting genotype-specific hypersensitive cell death. Plant Cell 8:1095-1105.

Guttman, D. S., Vinatzer, B. A., Sarkar, S. F., Ranall, M. V., Kettler, G., and Greenberg, J. T. 2002. A functional screen for the Type III (Hrp) secretome of the plant pathogen Pseudomonas syringae. Science 295:1722-1726.

Hacker, J., and Kaper, J. B. 2000. Pathogenicity islands and the evolution of microbes. Annu. Rev. Microbiol. 54:641-679.

Ham, J. H., Bauer, D. W., Fouts, D. E., and Collmer, A. 1998. A cloned Erwinia chrysanthemi Hrp (type III protein secretion) system functions in Escherichia coli to deliver Pseudomonas syringae Avr signals to plant cells and to secrete Avr proteins in culture. Proc. Natl. Acad. Sci. U.S.A. 95:10206-10211

Ham, J. H., Cui, Y. Y., Alfano, J. R., Rodrigues-Palenzuela, P., Rojas, C. M., Chatterjee, A. K., and Collmer, A. 2004. Analysis of Erwinia chrysanthemi EC16 pelE::uidA, pelL::uidA, and hrpN::uidA mutants reveals strain-specific atypical regulation of the Hrp type III secretion system. Mol. Plant-Microbe Interact. 17:184-194.

He, S. Y., and Collmer, A. 1990. Molecular cloning, nucleotide sequence and marker-exchange mutagenesis of the exo-poly- $\alpha$-D-galacturonosidase-encoding pehX gene of Erwinia chrysanthemi EC16. J. Bacteriol. 172:4988-4995.

Huang, H.-C., Lin, R.-W., Chang, C.-J., Collmer, A., and Deng, W.-L. 1995. The complete hrp gene cluster of Pseudomonas syringae pv. syringae 61 includes two blocks of genes required for harpin Pss $_{\text {secre- }}$ tion that are arranged colinearly with Yersinia ysc homologs. Mol. Plant-Microbe Interact. 8:733-746.

Keen, N. T. 1990. Gene-for-gene complementarity in plant-pathogen interactions. Annu. Rev. Genet. 24:447-463.

Keen, N. T., Ridgway, D., and Boyd, C. 1992. Cloning and characterization of a phospholipase gene from Erwinia chrysanthemi EC16. Mol Microbiol. 6:179-187.

Kim, J. F., and Alfano, J. R. 2002. Pathogenicity islands and virulence plasmids of bacterial plant pathogens. Curr. Topic Microbiol. Immunol. 264/2:127-147.

Kim, J. F., Charkowski, A. O., Alfano, J. R., Collmer, A., and Beer, S. V. 1998a. Sequences related to transposable elements and bacteriophages flank avirulence genes of Pseudomonas syringae. Mol. Plant-Microbe Interact. 11:1247-1252.

Kim, J. F., Ham, J. H., Bauer, D. W., Collmer, A., and Beer, S. V. 1998b. The $h r p C$ and $h r p N$ operons of Erwinia chrysanthemi EC16 are flanked by $p l c A$ homologs of hemolysin/adhesin genes and accompanying activator/transporter genes. Mol. Plant-Microbe Interact. 11:563-567.

Kim, J. F., Wei, Z.-M., and Beer, S. V. 1997. The $h r p A$ and $h r p C$ operons of Erwinia amylovora encode components of a type III pathway that secretes harpin. J. Bacteriol. 179:1690-1697.

King, E. O., Ward, M. K., and Raney, D. E. 1954. Two simple media for the demonstration of pyocyanin and fluorescin. J. Lab. Clin. Med. 44:301-307.

Leister, R. T., Ausubel, F. M., and Katagiri, F. 1996. Molecular recognition of pathogen attack occurs inside of plant cells in plant disease resistance specified by the Arabidopsis genes RPS2 and RPMI Proc. Natl. Acad. Sci. U.S.A. 93:15497-15502.

Lidell, M. C., and Hutcheson, S. W. 1994. Characterization of the hrpJ and hrpU operons of Pseudomonas syringae pv. syringae Pss61: similarity with components of enteric bacteria involved in flagellar biogenesis and demonstration of their role in harpin ${ }_{\text {Pss }}$ secretion. Mol. PlantMicrobe Interact. 7:488-497.

Lloyd, S. A., Forsberg, A., Wolf-Watz, H., and Francis, M. S. 2001. Targeting exported substrates to the Yersinia TTSS: different functions for different signals? Trends Microbiol. 9:367-371.

Lopez-Solanilla, E., Garcia-Olmedo, F., and Rodriguez-Palenzuela, P. 1998. Inactivation of the sapA to sapF locus of Erwinia chrysanthemi reveals common features in plant and animal bacterial pathogenesis. Plant Cell 10:917-924.

López-Solanilla, E., Llama-Palacios, A., Collmer, A., García-Olmedo, F. and Rodríguez-Palenzuela, P. 2001. Relative effects on virulence of mutations in the sap, pel and hrp loci of Erwinia chrysanthemi. Mol. Plant-Microbe Interact. 14:386-393.

Miller, J. H. 1992. A Short Course in Bacterial Genetics: A Laboratory Manual and Handbook for Escherichia coli and Related Bacteria. Cold Spring Harbor Laboratory Press, Cold Spring Harbor, NY, U.S.A.

Mor, H., Manulis, S., Zuck, M., Nizan, R., Coplin, D. L., and Barash, I. 2001. Genetic organization of the hrp gene cluster and $d s p A E / B F$ operon in Erwinia herbicola pv. gypsophilae. Mol. Plant-Microbe Interact. 14:431-436

Nizan, R., Barash, I., Valinsky, L., Lichter, A., and Manulis, S. 1997. The presence of $h r p$ genes on the pathogenicity-associated plasmid of the tumorigenic bacterium Erwinia herbicola pv. gypsophilae. Mol. PlantMicrobe Interact. 10:677-682.

Noel, L., Thieme, F., Nennstiel, D., and Bonas, U. 2002. Two novel type III-secreted proteins of Xanthomonas campestris pv. vesicatoria are encoded within the hrp pathogenicity island. J. Bacteriol. 184:1340-8.

Okinaka, Y., Yang, C. H., Perna, N. T., and Keen, N. T. 2002. Microarray profiling of Erwinia chrysanthemi 3937 genes that are regulated during plant infection. Mol. Plant-Microbe Interact. 15:619-29.

Petnicki-Ocwieja, T., Schneider, D. J., Tam, V. C., Chancey, S. T., Shan, L., Jamir, Y., Schechter, L. M., Buell, C. R., Tang, X., Collmer, A., and Alfano, J. R. 2002. Genomewide identification of proteins secreted by the Hrp type III protein secretion system of Pseudomonas syringae pv. 
tomato DC3000. Proc. Natl. Acad. Sci. U.S.A. 99:7652-7657.

Pirhonen, M., Saarilahti, H., Karlsson, M.-J., and Palva, E. T. 1991. Identification of pathogenicity determinants of Erwinia carotovora subsp. carotovora by transposon mutagenesis. Mol. Plant-Microbe Interact. 4:276-283.

Preston, G., Huang, H.-C., He, S. Y., and Collmer, A. 1995. The HrpZ proteins of Pseudomonas syringae pvs. syringae, glycinea, and tomato are encoded by an operon containing Yersinia ysc homologs and elicit the hypersensitive response in tomato but not soybean. Mol. Plant-Microbe Interact. 8:717-732.

Quigley, N., and Reeves, P. R. 1987. Chloramphenicol resistance cloning vector based on pUC9. Plasmid 17:54-57.

Ramamurthi, K. S., and Schneewind, O. 2002. Type III protein secretion in Yersinia species. Annu. Rev. Cell Dev. Biol. 18:107-133.

Ried, J. L., and Collmer, A. 1987. An npt-sacB-sacR cartridge for constructing directed, unmarked mutations in gram-negative bacteria by marker exchange-eviction mutagenesis. Gene 57:239-246.

Robert-Baudouy, J., Nasser, W., Condemine, G., Reverchon, S. Schevchik, S., and Hugouvieux-Cotte-Pattat, N. 2000. Pectic enzymes of Erwinia chrysanthemi, regulation and role in pathogenesis. Pages 221-268 in: Plant-Microbe Interactions, Vol. 5. G. Stacey and N. T. Keen, eds. American Phytopathological Society Press, St. Paul, MN, U.S.A.

Roeder, D. L., and Collmer, A. 1985. Marker-exchange mutagenesis of a pectate lyase isozyme gene in Erwinia chrysanthemi. J. Bacteriol. 164:51-56.

Rojas, C. M., Ham, J. H., Deng, W.-L., Doyle, J. J., and Collmer, A. 2002. HecA, a member of a class of adhesins produced by diverse pathogenic bacteria, contributes to the attachment, aggregation, epidermal cell killing, and virulence phenotypes of Erwinia chrysanthemi EC16 on Nicotiana clevelandii seedlings. Proc. Natl. Acad. Sci. U.S.A. 99:1314213147.

Salanoubat, M., Genin, S., Artiguenave, F., Gouzy, J., Mangenot, S., Arlat, M., Billault, A., Brottier, P., Camus, J. C., Cattolico, L., Chandler, M. Choisne, N., Claudel-Renard, C., Cunnac, S., Demange, N., Gaspin, C.,
Lavie, M., Moisan, A., Robert, C., Saurin, W., Schiex, T., Siguier, P. Thebault, P., Whalen, M., Wincker, P., Levy, M., Weissenbach, J., and Boucher, C. A. 2002. Genome sequence of the plant pathogen Ralstonia solanacearum. Nature 415:497-502.

Sambrook, J., Fritsch, E. F., and Maniatis, T. 1989. Molecular Cloning: A Laboratory Manual, 2nd ed. Cold Spring Harbor Laboratory Press, Cold Spring Harbor, NY, U.S.A.

Schechter, L. M., Roberts, K. A., Jamir, Y., Alfano, J. R., and Collmer, A. 2004. Pseudomonas syringae type III secretion system targeting signals and novel effectors studied with a Cya translocation reporter. J. Bacteriol. 186:543-555.

Schweizer, H. P. 1991. Escherichia-Pseudomonas shuttle vectors derived from pUC18/19. Gene 97:109-112.

Sory, M.-P., and Cornelis, G. R. 1994. Translocation of a hybrid YopEadenylate cyclase from Yersinia enterocolitica into HeLa cells. Mol. Microbiol. 14:583-594.

Van Gijsegem, F., Gough, C., Zischek, C., Niqueux, E., Arlat, M., Genin, S., Barberis, P., German, S., Castello, P., and Boucher, C. 1995. The hrp gene locus of Pseudomonas solanacearum, which controls the production of a type III secretion system, encodes eight proteins related to components of the bacterial flagellar biogenesis complex. Mol. Microbiol. 15:1095-1114.

Wu, Y., Wood, M. D., Tao, Y., and Katagiri, F. 2003. Direct delivery of bacterial avirulence proteins into resistant Arabidopsis protoplasts leads to hypersensitive cell death. Plant J. 33:131-137.

Yang, C.-H., Gavilanes-Ruiz, M., Okinaka, Y., Vedel, R., Berthuy, I., Boccara, M., Chen, J. W.-T., Perna, N. T., and Keen, N. T. 2002. hrp genes of Erwinia chrysanthemi 3937 are important virulence factors. Mol. Plant-Microbe Interact. 15:472-480.

Zhang, Y., and Geider, K. 1999. Molecular analysis of the $r l s A$ gene regulating levan production by the fireblight pathogen Erwinia amylovora. Physiol. Mol. Plant Pathol. 54:187-201.

Zhu, W., MaGbanua, M. M., and White, F. F. 2000. Identification of two novel hrp-associated genes in the hrp gene cluster of Xanthomonas oryzae pv. oryzae. J. Bacteriol. 182:1844-1853. 